\title{
Soil-atmosphere exchange of nitrous oxide, methane and carbon dioxide in a gradient of elevation in the coastal Brazilian Atlantic forest
}

\author{
E. Sousa Neto ${ }^{1}$, J. B. Carmo ${ }^{2}$, M. Keller ${ }^{3}$, S. C. Martins $^{1}$, L. F. Alves ${ }^{4}$, S. A. Vieira ${ }^{1}$, M. C. Piccolo ${ }^{1}$, P. Camargo ${ }^{1}$, \\ H. T. Z. Couto ${ }^{5}$, C. A. Joly ${ }^{6}$, and L. A. Martinelli ${ }^{1}$ \\ ${ }^{1}$ Centro de Energia Nuclear na Agricultura, CENA-USP, Laboratório de Ecologia Isotópica, Piracicaba, São Paulo, Brazil \\ ${ }^{2}$ Universidade Federal de São Carlos, Sorocaba, São Paulo, Brazil \\ ${ }^{3}$ International Institute of Tropical Forestry, USDA Forest Service, San Juan, Puerto Rico \\ ${ }^{4}$ INSTAAR, University of Colorado, Boulder CO, USA, and Instituto de Botânica, Seção de Ecologia, São Paulo, Brazil \\ ${ }^{5}$ Escola Superior de Agricultura Luiz de Queiroz, ESALQ-USP, Piracicaba, São Paulo, Brazil \\ ${ }^{6}$ Universidade Estadual de Campinas, Departamento de Biologia Vegetal - IB/UNICAMP, Brazil
}

Received: 14 June 2010 - Published in Biogeosciences Discuss.: 5 July 2010

Revised: 16 February 2011 - Accepted: 9 March 2011 - Published: 21 March 2011

\begin{abstract}
Soils of tropical forests are important to the global budgets of greenhouse gases. The Brazilian Atlantic Forest is the second largest tropical moist forest area of South America, after the vast Amazonian domain. This study aimed to investigate the emissions of nitrous oxide $\left(\mathrm{N}_{2} \mathrm{O}\right)$, carbon dioxide $\left(\mathrm{CO}_{2}\right)$ and methane $\left(\mathrm{CH}_{4}\right)$ fluxes along an altitudinal transect and the relation between these fluxes and other climatic, edaphic and biological variables (temperature, fine roots, litterfall, and soil moisture). Annual means of $\mathrm{N}_{2} \mathrm{O}$ flux were $3.9( \pm 0.4), 1.0( \pm 0.1)$, and $0.9( \pm 0.2)$ $\mathrm{ng} \mathrm{N} \mathrm{cm}{ }^{-2} \mathrm{~h}^{-1}$ at altitudes 100,400 , and $1000 \mathrm{~m}$, respectively. On an annual basis, soils consumed $\mathrm{CH}_{4}$ at all altitudes with annual means of $-1.0( \pm 0.2),-1.8( \pm 0.3)$, and $-1.6( \pm 0.1) \mathrm{mg} \mathrm{m}^{-2} \mathrm{~d}^{-1}$ at $100 \mathrm{~m}, 400 \mathrm{~m}$ and $1000 \mathrm{~m}$, respectively. Estimated mean annual fluxes of $\mathrm{CO}_{2}$ were 3.5, 3.6, and $3.4 \mu \mathrm{mol} \mathrm{m}^{-2} \mathrm{~s}^{-1}$ at altitudes 100,400 and $1000 \mathrm{~m}$, respectively. $\mathrm{N}_{2} \mathrm{O}$ fluxes were significantly influenced by soil moisture and temperature. Soil-atmosphere exchange of $\mathrm{CH}_{4}$ responded to changes in soil moisture. Carbon dioxide emissions were strongly influenced by soil temperature. While the temperature gradient observed at our sites is only an imperfect proxy for climatic warming, our results suggest that an increase in air and soil temperatures may result in increases in decomposition rates and gross inorganic nitrogen fluxes that could support consequent increases in soil $\mathrm{N}_{2} \mathrm{O}$ and $\mathrm{CO}_{2}$ emissions and soil $\mathrm{CH}_{4}$ consumption.
\end{abstract}

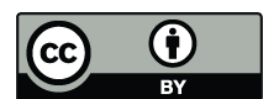

Correspondence to: E. Sousa Neto (eraklito@gmail.com)

\section{Introduction}

The Brazilian Atlantic Forest is a heterogeneous region that includes a large variety of forest physiognomies and compositions (plant and animal species) and is distributed in different topographic and climatic conditions such as areas of coastal flooded forest (restinga), lowland, submontane and montane forests (Metzger, 2009; Vieira et al., 2008). It originally covered an area of 148 million ha, corresponding approximately to $17.4 \%$ of the Brazilian territory, extending for over $3300 \mathrm{~km}$ along the eastern Brazilian coast between the latitudes of 3 and $30^{\circ} \mathrm{S}$ (Metzger, 2009; Ribeiro et al., 2009). The Atlantic forest represents the second largest tropical moist ecosystem of South America, after the vast Amazonian domain (Oliveira-Filho and Fontes, 2000), and it is also considered a hotspot in terms of biodiversity and endemism (Myers et al., 2000). Nevertheless, the Atlantic Forest is among the most threatened tropical forests in the world because its location coincides largely with the most populated areas of Brazil, where the settlement of European pioneers and African slaves started four centuries ago (OliveiraFilho and Fontes, 2000). Currently the Atlantic Forest is reduced to only $12 \%$ of its original cover (Metzger, 2009), and most remnants are small and disturbed fragments $(<50 \mathrm{ha})$ or larger areas sheltered on steep mountain slopes (Metzger, 2009; Ribeiro et al., 2009).

Despite the importance of the Atlantic Forest biome there are very few data concerning its function (Maddock et al., 2001). Soils of tropical forests are considered as important contributors to the global gas budgets as a source of

Published by Copernicus Publications on behalf of the European Geosciences Union. 
atmospheric nitrous oxide (Bouwman et al., 1995; Maddock et al., 2001), and carbon dioxide (Keller et al., 1986), and as a sink of methane (Reiners et al., 1994; Reiners et al., 1997). Although considerable research has been made on quantifying the global sources of the main greenhouse gases $\left(\mathrm{N}_{2} \mathrm{O}\right.$, $\mathrm{CH}_{4}$, and $\mathrm{CO}_{2}$ ) the uncertainties in the overall budgets of these gases remain large in part because of the limited spatial and temporal extent of the sampling in tropical regions (Maddock et al., 2001; Purbopuspito et al., 2006).

The main objective of this paper is to quantify the soil emission rates of $\mathrm{N}_{2} \mathrm{O}, \mathrm{CH}_{4}$ and $\mathrm{CO}_{2}$ along a gradient of elevation in the Coastal Brazilian Atlantic Forest located in the northern coast of São Paulo state, southeast region of Brazil. Most studies related to tropical forest soil emissions are still strongly biased toward lowland tropical forests (Keller and Reiners, 1994; Davidson et al., 2000, 2001).We chose to work along a gradient of elevation because of differences in climatic conditions, species composition and structure (Marrs et al., 1988), nutrient supply (Grubb, 1977) and soil physical and chemical properties (Sollins, 1998; Tanner et al., 1998). Climate and soil properties are well known factors that modulate the emission of trace gases by soils (Davidson, 1993; Steudler et al., 1996; Breuer et al., 2000; Davidson et al., 2000; Kiese and Butterbach-Bahl, 2002; Moreira and Siqueira, 2006). Therefore, we expected soil gas emissions to vary with altitude responding to combinations of the factors described above. Although tropical forest soils are expected to respond to global warming few studies have investigated soils from forests along a gradient of elevation that might provide some insight into controls on future trace gas exchange (Riley and Vitousek, 1995; Purbopuspito et al., 2006).

\section{Material and methods}

\subsection{Study area}

This study was conducted in the Coastal Brazilian Atlantic Forest, on the northern coast of the São Paulo State, within the management units (nucleos) of Picinguaba (lowland, $23^{\circ} 31^{\prime}$ to $23^{\circ} 34^{\prime} \mathrm{S}$ and $45^{\circ} 02^{\prime}$ to $45^{\circ} 05 \mathrm{~W}$ ) and Santa Virginia (montane, $23^{\circ} 17^{\prime}$ to $23^{\circ} 24^{\prime} \mathrm{S}$ and $45^{\circ} 03^{\prime}$ to $45^{\circ} 11^{\prime} \mathrm{W}$ ) of the Serra do Mar State Park. Three areas (treatments) were selected at the altitudes of $100 \mathrm{~m}$ (lowland), $400 \mathrm{~m}$ (submontane), and $1000 \mathrm{~m}$ (montane) (Alves et al., 2010). Historical monthly average temperatures of the study areas ranges from 19.1 to $25.5^{\circ} \mathrm{C}$ (Sentelhas et al., 1999). According to Oliveira-Filho and Fontes (2000) and Talora et al. (2000), the lowland and submontane areas $(100 \mathrm{~m}$ and $400 \mathrm{~m})$ are characterized as tropical moist forests under a tropical climate (Af type in Köppen), whereas the montane area (1000 m) is considered a tropical montane forest (Tabarelli and Mantovani, 2000) under subtropical climate (Cfa according to Köppen). For a full description of the forest classification and structure see Alves et al. (2010).
According to the meteorological stations of the Department of Water and Energy of São Paulo State (DAEE-SP) the historical annual mean precipitation (1973-2004) at the municipality of Ubatuba located at $220 \mathrm{~m}$ altitude is $3050 \mathrm{~mm}$ and in the municipality of Natividade da Serra, near altitude $1000 \mathrm{~m}$, the annual mean precipitation decreases to approximately $2300 \mathrm{~mm}$. During May through August, the total historical precipitation is $200 \mathrm{~mm}$, about half as much as in other months. In this study we considered these four months as dry season and the other eight months as rainy season.

Soils of the study sites are mostly sandy, but with higher clay contents at $100 \mathrm{~m}$ (Table 1). Compared to other tropical forests in the world (Purbopuspito et al, 2006; Campo et al., 2007; Arnold et al., 2009), soils at the three altitudes of the Brazilian Atlantic Forest have low carbon (C) and nitrogen $(\mathrm{N})$ contents and these nutrients are concentrated in the upper soil layer (up to $10 \mathrm{~cm}$ depth), decreasing with depth (Martins, 2010). Soil C and N concentrations and stocks progressively increase along the altitudinal gradient (Table 1). Similar C and $\mathrm{N}$ contents were found in soils in the Brazilian Amazon basin (Nardoto et al., 2008).

\subsection{Soil gas flux}

At each altitude four plots (replicates) of 1 ha were delimited (Alves et al., 2010). Gas samples were collected once a month from September 2006 through August 2007, in each plot with a day of collection per altitude, generally between 08:00 and 18:00 h LT. Fluxes of nitrous oxide $\left(\mathrm{N}_{2} \mathrm{O}\right)$, carbon dioxide $\left(\mathrm{CO}_{2}\right)$, and methane $\left(\mathrm{CH}_{4}\right)$ were measured at random points along $30 \mathrm{~m}$ transects that were initiated at randomized seed points in randomized directions each month with eight cylindrical PVC chambers (8 sub-sample chambers per plot) consisting of a pipe that served as a base ( $0.29 \mathrm{~m}$ diameter) and a cap that fit snugly on the base (Keller et al., 2005). For $\mathrm{N}_{2} \mathrm{O}$ and $\mathrm{CH}_{4}$, four samples of $60 \mathrm{~mL}$ of the air from the chambers were withdrawn at intervals of 1 , 10,20 and $30 \mathrm{~min}$ after closing with $60 \mathrm{~mL}$ syringes and then transferred to previously evacuated glass serum vials sealed with gas impermeable, butyl rubber septum stoppers. Samples were analyzed by gas chromatography (SHIMADZU GC-14A Model) within five days of collection. Lab tests showed that $\mathrm{N}_{2} \mathrm{O}$ and $\mathrm{CH}_{4}$ concentrations were unaffected by storage for up to thirty days. Gas concentrations were calculated by comparing peak areas for samples to those of commercially prepared standards (Scott-Marin) that had been calibrated against standards prepared by the National Oceanic and Atmospheric Administration/Climate Monitoring and Diagnostic Laboratory (NOAA/CMDL). Fluxes were calculated from linear regressions of concentration versus time. 
Table 1. Physical-Chemical characterization of the soil layers $(0.3 \mathrm{~m}$ depth) sampled at the studied sites (mean \pm standard error; $n=32$ for each altitude and depth). Data source: Martins, 2010.

\begin{tabular}{lccccc}
\hline $\begin{array}{l}\text { Depth } \\
(\mathrm{cm})\end{array}$ & $\mathrm{N}$ & $\begin{array}{c}\mathrm{C} \\
\left(\mathrm{g} \mathrm{kg}^{-1}\right)\end{array}$ & Sand & Clay & $\begin{array}{c}\text { Bulk Density } \\
(\%)\end{array}$ \\
\hline $100 \mathrm{~m}$ & & & & & \\
$0-5$ & $3.4 \pm 1.4$ & $45.9 \pm 19.4$ & $60.4 \pm 9.7$ & $31.5 \pm 8.0$ & $0.9 \pm 0.1$ \\
$5-10$ & $2.4 \pm 1.1$ & $31.8 \pm 15.3$ & $56.5 \pm 9.3$ & $35.1 \pm 8.6$ & $1.1 \pm 0.1$ \\
$10-20$ & $1.9 \pm 0.7$ & $25.9 \pm 10.1$ & $56.8 \pm 9.9$ & $35.3 \pm 9.7$ & $1.3 \pm 0.1$ \\
$20-30$ & $1.2 \pm 0.4$ & $16.5 \pm 5.9$ & $55.8 \pm 9.6$ & $37.4 \pm 9.7$ & $1.4 \pm 0.1$ \\
\hline $400 \mathrm{~m}$ & & & & & \\
$0-5$ & $4.6 \pm 1.1$ & $58.9 \pm 15.5$ & $66.7 \pm 6.6$ & $16.4 \pm 3.8$ & $1.0 \pm 0.0$ \\
$5-10$ & $3.6 \pm 0.8$ & $45.8 \pm 12.7$ & $62.2 \pm 3.8$ & $20.5 \pm 3.7$ & $1.1 \pm 0.1$ \\
$10-20$ & $2.7 \pm 0.5$ & $34.7 \pm 8.8$ & $61.4 \pm 6.0$ & $22.1 \pm 4.5$ & $1.2 \pm 0.1$ \\
$20-30$ & $2.0 \pm 0.3$ & $26.0 \pm 5.9$ & $59.5 \pm 5.9$ & $23.4 \pm 4.2$ & $1.3 \pm 0.1$ \\
\hline $1000 \mathrm{~m}$ & & & & & \\
$0-5$ & $6.8 \pm 3.1$ & $91.5 \pm 45.3$ & $57.3 \pm 12.2$ & $20.3 \pm 8.5$ & $0.8 \pm 0.2$ \\
$5-10$ & $4.5 \pm 1.5$ & $58.8 \pm 21.2$ & $53.9 \pm 14.3$ & $22.3 \pm 10.8$ & $0.8 \pm 0.2$ \\
$10-20$ & $3.8 \pm 1.2$ & $49.6 \pm 17.1$ & $54.0 \pm 12.2$ & $19.8 \pm 10.7$ & $1.0 \pm 0.2$ \\
$20-30$ & $3.1 \pm 1.2$ & $44.4 \pm 22.5$ & $53.5 \pm 12.3$ & $20.6 \pm 11.5$ & $1.1 \pm 0.2$ \\
\hline
\end{tabular}

A dynamic flow system was used for measurements of $\mathrm{CO}_{2}$. Air flowed from the soil enclosure through a Teflonlined polyethylene sample line $5 \mathrm{~m}$ in length and then it entered an infrared gas analyzer (Li-Cor 820). Data were stored in a palmtop computer and fluxes were calculated from the linear increase of concentration versus time adjusted for the ratio of chamber volume to area and the air density within the chamber (Keller et al., 2005). Because of instrument malfunctions, $\mathrm{CO}_{2}$ fluxes were not available for several months of the year (see Results).

\subsection{Litterfall and fine roots}

Litterfall data were obtained by thirty $80 \mathrm{~cm}$ diameter litterfall traps per plot deployed at randomized points in two plots at each elevation and samples were collected every fifteen days, kept in paper bags, labeled, and dried at $60^{\circ} \mathrm{C}$. After drying, samples were weighed. In addition, surface litter layer mass was weighed to assess litterfall stocks simultaneously with litterfall. Thirty surface litter samples were collected from randomly located $0.3 \times 0.3 \mathrm{~m}$ plots marked by a rigid frame for two plots at each altitude, every thirty days. Samples were kept in paper bags, dried at $60^{\circ} \mathrm{C}$ and weighed to determine stocks of litter on soil surface. Litterfall and surface litter collections started six months after gas sampling (March 2007) and therefore overlapped the gas collections for only 6 months (March through August 2007). Decomposition rates were calculated according to the model proposed by Olson (1963) and decomposition time was determined according to Shanks and Olson (1961).
Five fine root soil cores samples were randomly collected from 0 to $10 \mathrm{~cm}$ depth in every plot of each altitude, and treated according to Vogt and Persson (1991). Fine root samples were analyzed for total $\mathrm{C}$ and $\mathrm{N}$ concentration using a Carlo Erba elemental analyzer at the Laboratory of Isotope Ecology, CENA-USP. For statistical tests, the mean of the five root samples collected at each plot was considered as one of the four replicates per gradient of elevation.

\subsection{Soil water filled pore space (WFPS) and N contents}

Once a month during one year of collection, and after soil gas collection, the surface litter was removed from each chamber location and a soil core about $5 \mathrm{~cm}$ diameter and $10 \mathrm{~cm}$ deep was collected. After collection, soil samples were transported on ice in an insulated cooler to the Laboratory of Isotope Ecology at CENA-USP and stored at $\sim 4{ }^{\circ} \mathrm{C}$ until analysis. Soil samples were sieved (sieve $2 \mathrm{~mm}$ mesh) to remove roots and large stones, and a ten grams subsample was oven-dried at $105^{\circ} \mathrm{C}$ for $24 \mathrm{~h}$ to determine water content gravimetrically and $\mathrm{N}$ contents $\left(\mathrm{NH}_{4}^{+}\right.$and $\left.\mathrm{NO}_{3}^{-}\right)$, and $\mathrm{N}$-mineralization and $\mathrm{N}$-nitrification processes as the procedures described by Piccolo et al. (1994).

The main processes producing $\mathrm{N}_{2} \mathrm{O}$ are microbial and are nitrification and denitrification. These processes are strongly influenced by soil moisture content (Firestone and Davidson 1989; Davidson, 1993). In order to assess the relation between $\mathrm{N}_{2} \mathrm{O}$ fluxes and soil moisture we estimated the water filled pore space (WFPS) which is thought to be an important factor controlling N-oxide emissions from soil. Thus, WFPS was evaluated from soil core samples collected once a 


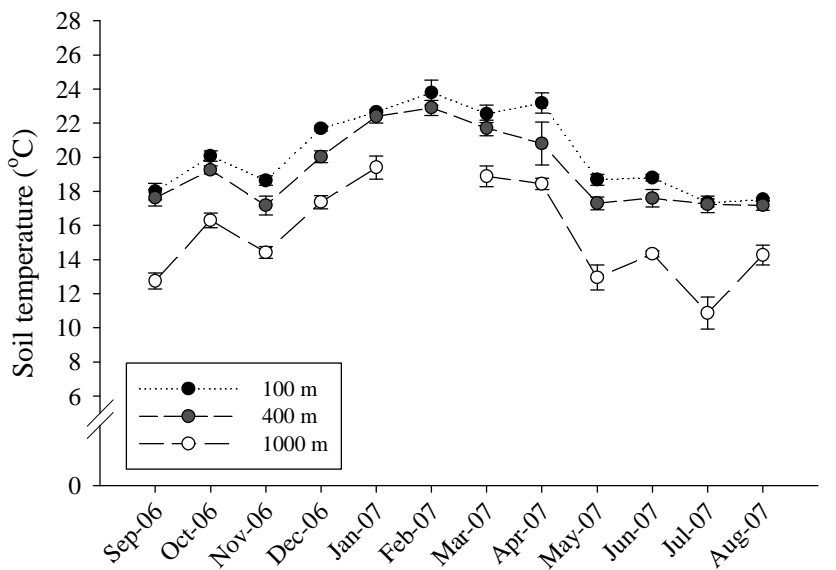

Fig. 1. Monthly soil temperatures $(2 \mathrm{~cm}$ depth) at the three different elevations. Values represent the mean of four replicate plots per elevation, and error bars represent the standard error. Because of weather conditions it was not possible to access the sites at altitude $1000 \mathrm{~m}$ in February 2007.

month from each chamber location and calculated according to Carmo et al. (2007). Additionally, we recorded air and soil temperatures $(2 \mathrm{~cm}$ depth) using electronic thermometers.

\subsection{Statistical analysis}

All data were first tested for normal distribution and for homoscedasticity by the Kolmogorov-Smirnov test. Because of the non-normal distribution of the fluxes for $\mathrm{CH}_{4}$ and $\mathrm{N}_{2} \mathrm{O}$, these data were log-transformed to homogenize variances. We analyzed gas fluxes and other variables in a 2way ANOVA design using altitude and month as treatments. Four plots served as replicates at each altitude. Months could be considered as treatments because the collection points for chambers were randomized every month. Tukey's posthoc analysis was used to make comparisons among altitudes. Pearson correlation coefficients between $\mathrm{N}_{2} \mathrm{O}, \mathrm{CO}_{2}$, and $\mathrm{CH}_{4}$ fluxes, soil $\mathrm{N}$ contents, soil temperature, and soil moisture also were calculated. Statistical analyses were performed using Minitab version 15 software (Minitab Inc., 2006).

Cumulative annual flux of $\mathrm{N}_{2} \mathrm{O}$ and $\mathrm{CH}_{4}$ were calculated by linear interpolation and integration of fluxes among the sampling dates. The difference among cumulative annual fluxes by altitude was also tested by one-way-ANOVA. Using an exponential model for $\mathrm{CO}_{2}$ flux with temperature (Doff Sotta et al., 2004), we estimated the missing $\mathrm{CO}_{2}$ data (October 2006 through April 2007) and then interpolated the data as we did for $\mathrm{N}_{2} \mathrm{O}$ and $\mathrm{CH}_{4}$ to estimate annual fluxes.

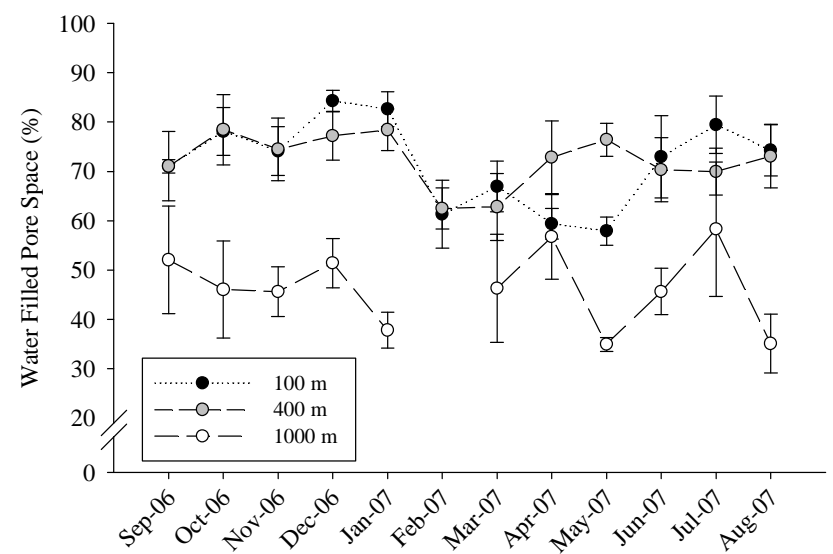

Fig. 2. Monthly variation of Water Filled Pore Space (WFPS) at different elevations. Values represent means of four replicates per elevation and bars represent standard errors. Because of weather conditions it was not possible to access the sites at altitude $1000 \mathrm{~m}$ in February 2007.

\section{Results}

\subsection{Soil temperature and soil chemical-physical properties}

As expected, lower soil temperatures $(P<0.05)$ were found at higher altitude $(1000 \mathrm{~m})$ and soil temperature increased at lower altitudes (Fig. 1).

Soil moisture expressed as WFPS was significantly higher $(P<0.05)$ in the plots at $100 \mathrm{~m}$ and $400 \mathrm{~m}$ than in soils located at $1000 \mathrm{~m}$ (Fig. 2). The trends in WFPS reflect in part the soil porosity and packing (Beare et al., 2009). Soil bulk densities at $5 \mathrm{~cm}$ depth were greater at the lower elevations $\left(0.98 \mathrm{~g} \mathrm{~m}^{3}\right.$ at $100 \mathrm{~m}$ and $1.06 \mathrm{Mg} \mathrm{m}^{3}$ at $\left.400 \mathrm{~m}\right)$ compared to the montane site $\left(0.8 \mathrm{~g} \mathrm{~m}^{3}\right.$ at $\left.1000 \mathrm{~m}\right)$.

There was no difference $(P>0.05)$ in annual net mineralization and net nitrification rates among altitudes. However, ammonium $\left(\mathrm{NH}_{4}^{+}\right)$and nitrate $\left(\mathrm{NO}_{3}^{-}\right)$concentrations were significantly higher $(P<0.05)$ at altitude $1000 \mathrm{~m}(9.7 \pm 0.6$ and $19.1 \pm 1.0 \mu \mathrm{g} \mathrm{g}^{-1}$, respectively). No significant correlations were found between soil nitrate or ammonium concentrations and flux of soil gases during the sampling period nor was soil net $\mathrm{N}$, net mineralization and net nitrification rates significantly correlated to soil gas emissions.

\subsection{Fine root and litter production}

On average total fine root biomass $(0-10 \mathrm{~cm}$ depth) was greater $(P<0.05)$ in the dry season than in the rainy season. During the rainy season fine roots had larger live mass $(P<0.05)$ than dead mass and fine root mass (live and dead) was larger $(P<0.05)$ at $1000 \mathrm{~m}$ (Table 2$)$. In the dry season, there was no significant difference $(P>0.05)$ between live and dead mass along the altitudes but greater root mass $(P<0.05)$ was again found at $1000 \mathrm{~m}$ altitude. 
Table 2. Fine root biomass (live and dead) at different altitudes in the rainy and in the dry season. Values represent mean and standard error of four replicates per altitude.

\begin{tabular}{lcccc}
\hline \multirow{2}{*}{$\begin{array}{l}\text { Altitude } \\
(\mathrm{m})\end{array}$} & \multicolumn{2}{c}{ Rainy season $\left(\mathrm{g} \mathrm{m}^{-2}\right)$} & \multicolumn{2}{c}{ Dry season $\left(\mathrm{g} \mathrm{m}^{-2}\right)$} \\
Live & Dead & Live & Dead \\
\hline $100 \mathrm{~m}$ & $204.2( \pm 28.1)^{\mathrm{a}}$ & $82.1( \pm 16.0)^{\mathrm{b}}$ & $433.8( \pm 119.1)^{\mathrm{a}}$ & $275.4( \pm 131.9)^{\mathrm{a}}$ \\
$400 \mathrm{~m}$ & $293.1( \pm 38.1)^{\mathrm{a}}$ & $143.34( \pm 17.4)^{\mathrm{b}}$ & $310.6( \pm 87.6)^{\mathrm{a}}$ & $219.5( \pm 98.2)^{\mathrm{a}}$ \\
$1000 \mathrm{~m}$ & $464.0( \pm 80.2)^{\mathrm{a}}$ & $220.7( \pm 44.5)^{\mathrm{b}}$ & $1098.3( \pm 89.8)^{\mathrm{a}}$ & $896.2( \pm 82.3)^{\mathrm{a}}$ \\
\hline
\end{tabular}

Lower case letters indicate difference between columns within seasons.

Table 3. Concentrations of carbon and nitrogen and C:N ratio of fine roots ( $<2 \mathrm{~mm}$ ) at different altitudes in rainy (January, 2007) and dry (August, 2007) months. Values represent mean and standard error (in parenthesis) of four replicates per altitude.

\begin{tabular}{lllccc}
\hline Season & Altitude $(\mathrm{m})$ & Category & $\mathrm{C}(\%)$ & $\mathrm{N}(\%)$ & $\mathrm{C}: \mathrm{N}$ \\
\hline Rainy & \multirow{2}{*}{$100 \mathrm{~m}$} & Live & $42.8( \pm 1.2)$ & $1.4( \pm 0.1)$ & $32.6( \pm 2.7) \mathrm{a}, \mathrm{A}$ \\
& & Dead & $37.8( \pm 1.4)$ & $1.5( \pm 0.1)$ & $26.5(0.1) \mathrm{b}, \mathrm{A}$ \\
& \multirow{2}{*}{$400 \mathrm{~m}$} & Live & $42.9( \pm 0.3)$ & $1.5( \pm 0.1)$ & $31.1( \pm 2.2) \mathrm{a}, \mathrm{A}$ \\
& & Dead & $38.0( \pm 2.4)$ & $1.4( \pm 0.1)$ & $27.1( \pm 0.5) \mathrm{b}, \mathrm{A}$ \\
& \multirow{2}{*}{$1000 \mathrm{~m}$} & Live & $45.4( \pm 1.0)$ & $1.3( \pm 0.1)$ & $35.7( \pm 2.1) \mathrm{a}, \mathrm{A}$ \\
& & Dead & $44.0( \pm 1.2)$ & $1.5( \pm 0.1)$ & $29.9( \pm 0.9) \mathrm{b}, \mathrm{A}$ \\
& & & & \\
\hline \multirow{2}{*}{ Dry } & & & & \\
& \multirow{2}{*}{$100 \mathrm{~m}$} & Live & $41.4( \pm 1.2)$ & $1.7( \pm 0.2)$ & $25.6( \pm 1.8) \mathrm{a}, \mathrm{B}$ \\
& & Dead & $37.4( \pm 0.5)$ & $1.7( \pm 0.1)$ & $22.1( \pm 1.5) \mathrm{b}, \mathrm{B}$ \\
& \multirow{4}{*}{$400 \mathrm{~m}$} & Live & $39.4( \pm 0.5)$ & $1.6( \pm 0.1)$ & $26.4( \pm 1.0) \mathrm{a}, \mathrm{B}$ \\
& & Dead & $37.2( \pm 1.0)$ & $1.7( \pm 0.2)$ & $22.3( \pm 1.7) \mathrm{b}, \mathrm{B}$ \\
& & & & \\
& \multirow{2}{*}{$1000 \mathrm{~m}$} & Live & $43.6( \pm 0.8)$ & $1.7( \pm 0.1)$ & $27.1( \pm 1.6) \mathrm{a}, \mathrm{B}$ \\
& & Dead & $39.6( \pm 0.9)$ & $1.7( \pm 0.1)$ & $23.3( \pm 1.4) \mathrm{b}, \mathrm{B}$ \\
\hline
\end{tabular}

Lower case letters indicate difference between altitudes within seasons and upper case letters indicate difference between seasons.

Carbon to nitrogen (C:N) ratio of fine roots (live and dead) collected during the rainy season was significantly higher $(P<0.05)$ than in the dry season (Table 3$)$. In both seasons, the $\mathrm{C}: \mathrm{N}$ ratio of live roots was significantly $(P<0.05)$ higher than in dead roots. There was no significant difference in $\mathrm{C}: \mathrm{N}$ ratio of fine roots among altitudes (Table 3).

Although a decrease in litterfall was observed at higher altitudes, there was no significant difference among altitudes (Table 4). Litterfall stocks on soil surface were significantly higher $(P<0.05)$ at $1000 \mathrm{~m}$ (Table 4$)$. Calculations using Shanks and Olson's model (1961), showed that litter decay rate decreases as altitude increases $(P<0.05$, Table 4$)$; litter takes 18 months for $95 \%$ loss at $100 \mathrm{~m}$ and about $50 \%$ more time at 400 and $1000 \mathrm{~m}$.

\subsection{Soil-atmosphere emissions of trace gases}

Annual means of soil $\mathrm{N}_{2} \mathrm{O}$ flux decreased $(P<0.05)$ with the increase of altitude (Table 5). At all altitudes, we observed consumption of soil $\mathrm{CH}_{4}$ with the smallest consumption $(P<0.05)$ observed at $100 \mathrm{~m}$ (Table 5). $\mathrm{CO}_{2}$ fluxes do not correspond to a full year and valid data correspond to the months from March to August 2007. For these months, soil $\mathrm{CO}_{2}$ fluxes averaged $3.1( \pm 0.3) \mu \mathrm{mol} \mathrm{m}^{-2} \mathrm{~s}^{-1}$ at $1000 \mathrm{~m}$ and were significantly lower $(P<0.05)$ than at $400 \mathrm{~m}$ and $100 \mathrm{~m}\left(3.3( \pm 0.3)\right.$ and $3.6( \pm 0.2) \mu \mathrm{mol} \mathrm{m}^{-2} \mathrm{~s}^{-1}$ respectively), which were not distinguishable from one another.

The cumulative annual fluxes of $\mathrm{N}_{2} \mathrm{O}$ and $\mathrm{CH}_{4}$ for the three altitudes were calculated and the ANOVA results for $\mathrm{N}_{2} \mathrm{O}$ were similar to the simple averages (Table 5). In contrast, for the cumulative fluxes of $\mathrm{CH}_{4}$ we found no significant difference among altitudes. We note that the simple data provide a more powerful test than the cumulative data because they include more degrees of freedom. 
Table 4. Litterfall inputs and stocks in different altitudes and litter decomposition rates $(k)$ and time (months) for decay of $50 \%\left(t_{0.5}\right)$ and $95 \%\left(t_{0.05}\right)$. Data represents six months of sampling (March through August 2007). Different letters represent statistically significant differences among altitudes.

\begin{tabular}{|c|c|c|c|c|c|}
\hline \multirow{2}{*}{$\begin{array}{l}\text { Altitude } \\
\text { (m) }\end{array}$} & \multicolumn{2}{|c|}{ Litterfall } & \multicolumn{3}{|c|}{ Forest Floor } \\
\hline & Inputs $\left(\mathrm{tha}^{-1} \mathrm{y}^{-1}\right)$ & Stocks $\left(\mathrm{tha}^{-1}\right)$ & $\mathrm{DC}^{1}(\mathrm{k})$ & $\mathrm{t}_{0.5}$ & $\mathrm{t}_{0.05}$ \\
\hline 100 & $8.4( \pm 1.5)^{\mathrm{a}}$ & $4.3( \pm 0.8)^{\mathrm{a}}$ & $2^{\mathrm{a}}$ & 3 & 18 \\
\hline 400 & $7.4( \pm 1.8)^{\mathrm{a}}$ & $4.4( \pm 0.4)^{\mathrm{a}}$ & $1.4^{\mathrm{b}}$ & 5 & 25 \\
\hline 1000 & $5.5( \pm 0.9)^{\mathrm{a}}$ & $4.8( \pm 0.6)^{b}$ & $1.3^{b}$ & 5 & 27 \\
\hline
\end{tabular}

${ }^{1} \mathrm{DC}=$ Decomposition coefficient

Table 5. Simple annual mean (SA) and integrated (Int.) fluxes of $\mathrm{N}_{2} \mathrm{O}$ and $\mathrm{CH}_{4}$ for different altitudes. Different letters represent statistically significant differences among the altitudes. See text for a description of the averaging and integration approaches.

\begin{tabular}{l|cc|cc}
\hline $\begin{array}{l}\text { Altitude } \\
(\mathrm{m})\end{array}$ & \multicolumn{2}{|c|}{$\mathrm{N}_{2} \mathrm{O}\left(\mathrm{ng} \mathrm{N} \mathrm{cm}^{-2} \mathrm{~h}^{-1}\right)$} & \multicolumn{2}{c}{$\mathrm{CH}_{4}\left(\mathrm{mg} \mathrm{CH}_{4} \mathrm{~m}^{-2} \mathrm{~d}^{-1}\right)$} \\
SA & Int. & $\mathrm{SA}$ & Int. \\
\hline 100 & $3.9^{\mathrm{a}}( \pm 0.4)$ & $4.4^{\mathrm{a}}( \pm 0.5)$ & $-1.0^{\mathrm{a}}( \pm 0.2)$ & $-1.0^{\mathrm{a}}( \pm 0.2)$ \\
400 & $1.0^{\mathrm{b}}( \pm 0.1)$ & $1.1^{\mathrm{b}}( \pm 0.1)$ & $-1.8^{\mathrm{b}}( \pm 0.3)$ & $-1.7^{\mathrm{a}}( \pm 0.3)$ \\
1000 & $0.9^{\mathrm{c}}( \pm 0.2)$ & $1.1^{\mathrm{b}}( \pm 0.3)$ & $-1.6^{\mathrm{b}}( \pm 0.1)$ & $-1.4^{\mathrm{a}}( \pm 0.1)$ \\
\hline
\end{tabular}

Higher fluxes of $\mathrm{CO}_{2}$ were observed in all altitudes between February and April, 2007, during the rainy season, and lower fluxes were measured between May and August, 2007, during dry season (Fig. 3c). Carbon dioxide emissions increased with soil temperature $\left(r^{2}=0.7\right.$ at $100 \mathrm{~m}, r^{2}=0.9$ at $400 \mathrm{~m}$ and $1000 \mathrm{~m}$, respectively, $P<0.05$ ), but no correlation was observed with WFPS.

The cumulative annual fluxes of $\mathrm{CO}_{2}$ were also estimated and values were $3.5,3.6$ and $3.4 \mu \mathrm{mol} \mathrm{m}^{-2} \mathrm{~s}^{-1}$ at altitudes $100 \mathrm{~m}, 400 \mathrm{~m}$, and $1000 \mathrm{~m}$ altitudes respectively. Based on the exponential model we also calculated $\mathrm{Q}_{10}$ values of 1.6, 2.3, and 2.1 at altitudes $100 \mathrm{~m}, 400 \mathrm{~m}$ and $1000 \mathrm{~m}$, respectively.

\subsection{Altitudinal and monthly variations of soil gas fluxes and their dependency on changes in soil temperature and WFPS}

At $100 \mathrm{~m}$ there was a significant $(P<0.05)$ variation in $\mathrm{N}_{2} \mathrm{O}$ fluxes during sampling period, with the highest fluxes measured in the rainy months of December 2006 and January 2007 (Fig. 3a). A significant positive correlation $\left(r^{2}=0.86\right.$, $P<0.05$ ) between soil moisture (WFPS) and $\mathrm{N}_{2} \mathrm{O}$ flux was observed exclusively at $100 \mathrm{~m}$ while there was no correlation between soil temperature and $\mathrm{N}_{2} \mathrm{O}$ flux at the same altitude.

Fluxes measured at $400 \mathrm{~m}$ showed significant differences along the sampling period, with the largest $\mathrm{N}_{2} \mathrm{O}$ emissions $(P<0.05)$ measured during the rainy season, between $\mathrm{Au}-$ gust 2006 and January 2007 (Fig. 3a). At $1000 \mathrm{~m}$ there was a weak but significant $(P<0.05)$ monthly variation of $\mathrm{N}_{2} \mathrm{O}$ fluxes, and the largest emissions were observed between the rainy months of November 2006 and January 2007 (Fig. 3a) whereas significantly $(P<0.05)$ lower fluxes were found in the dry months of July and August 2007. A weak but significant correlation $\left(r^{2}=0.52, P<0.05\right)$ between soil temperature and $\mathrm{N}_{2} \mathrm{O}$ fluxes was observed at altitude $1000 \mathrm{~m}$.

At $100 \mathrm{~m}$ soil-atmosphere exchange of $\mathrm{CH}_{4}$ showed only negative fluxes (soil consumption of atmospheric $\mathrm{CH}_{4}$ ) and consumption varied significantly $(P<0.05)$ among months. The largest consumption occurred in August 2006 (transition between rainy and dry seasons) and in the hot and wet period between February and March 2007 (rainy season). Smaller consumption was measured during the cool and dry months of June, July and August 2007 (Fig. 3b).

Methane consumption varied significantly $(P<0.05)$ among months at $400 \mathrm{~m}$ altitude. More consumption $(P<$ 0.05 ) occurred in the rainy months of September, 2006 and March, 2007 and less consumption was measured during November, 2006 and December, 2006 (rainy season) and in the dry month of June, 2007 (Fig. 3b). At $1000 \mathrm{~m}$ consumption of $\mathrm{CH}_{4}$ also varied among months $(P<0.05)$. The pattern was similar to the pattern at $400 \mathrm{~m}$ with less consumption $(P<0.05)$ in the rainy months of November and December 2006 and more $(P<0.05)$ consumption in September 2006 and August 2007 (Fig. 3b).

In general, there was no significant correlation between $\mathrm{CH}_{4}$ fluxes and soil temperature at any altitude. In contrast, $\mathrm{CH}_{4}$ correlated weakly $\left(r^{2}=0.40, P<0.05\right)$ with WFPS at $100 \mathrm{~m}$. 

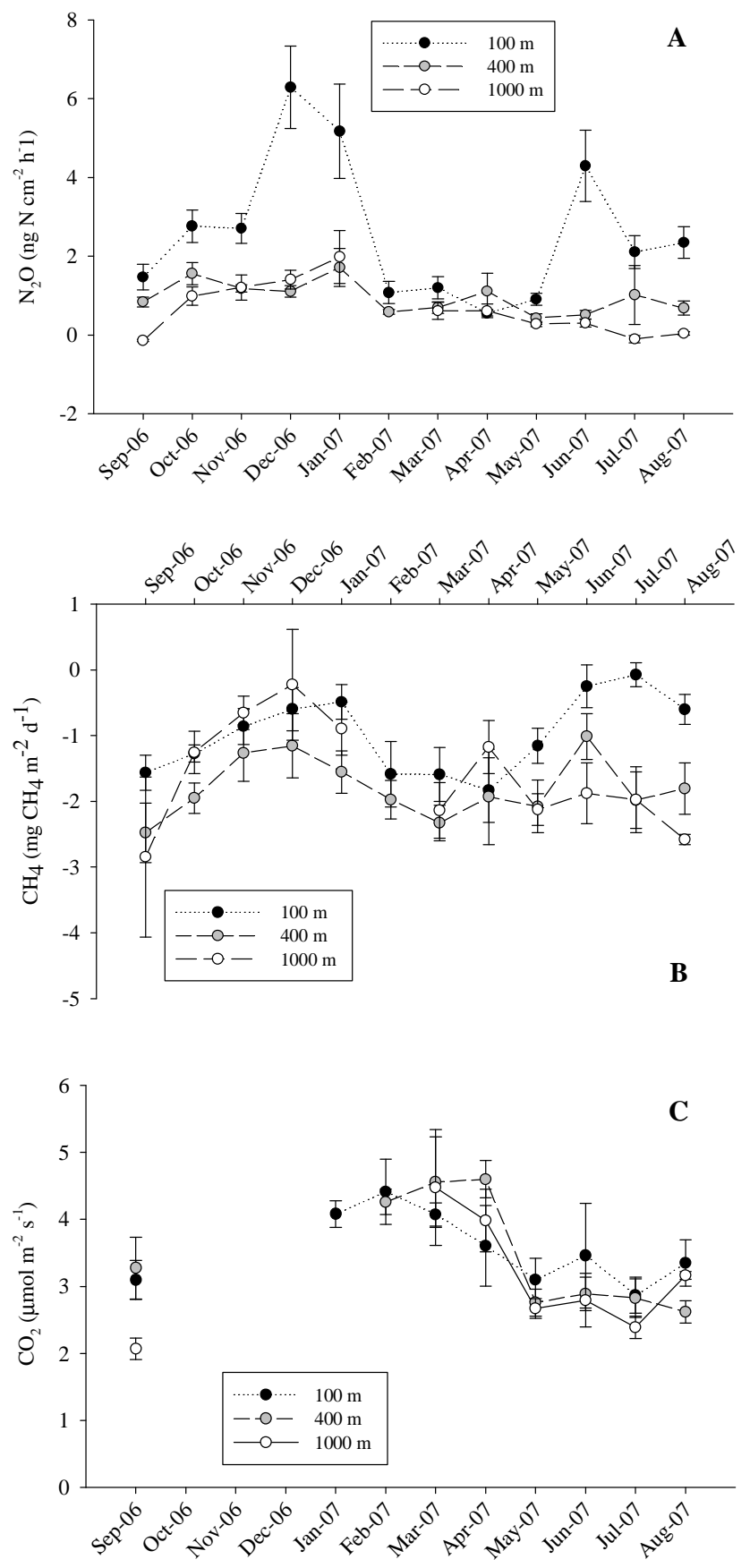

Fig. 3. Monthly soil-atmosphere gas flux of (A) nitrous oxide $\left(\mathrm{N}_{2} \mathrm{O}\right)$, (B) methane $\left(\mathrm{CH}_{4}\right)$, and $(\mathbf{C})$ carbon dioxide $\left(\mathrm{CO}_{2}\right)$ at different altitudes. Values represent the mean of four replicates per elevation and bars represent standard errors.

\section{Discussion}

\subsection{Soil-atmosphere emissions of $\mathrm{N}_{2} \mathrm{O}$}

In order to understand the decrease in soil $\mathrm{N}_{2} \mathrm{O}$ emissions with altitude we evaluate our data in relation to the hole-in- the-pipe (HIP) model (Firestone and Davidson, 1989; Davidson et al., 2000). According to this model, at a broad scale, $\mathrm{N}_{2} \mathrm{O}$ emissions increase with the nitrogen availability (gross inorganic nitrogen fluxes) in the system. Comparing different tropical regions, Davidson et al. (2000) found specifically that $\mathrm{N}_{2} \mathrm{O}$ emissions were correlated with soil nitrate concentrations, $\mathrm{N}$-mineralization and nitrification, and were inversely correlated with the soil ammonium concentrations or the ratio of ammonium to nitrate.

Our data do not follow the trends described by Davidson et al. (2000) and other studies. At the $1000 \mathrm{~m}$ forest site, soil concentrations of ammonium and nitrate were higher than at other sites and average nitrate concentrations were $30 \%$ higher than average ammonium concentrations. Soil pools of ammonium and nitrate reflect a balance in production and consumption processes and do not necessarily correlate with gas fluxes. Nonetheless, the low $\mathrm{N}_{2} \mathrm{O}$ fluxes at the montane site are at odds with the trends for higher $\mathrm{N}_{2} \mathrm{O}$ emissions where soil nitrate pools exceeded soil ammonium pools (Davidson et al., 2000). Despite the high nitrate to ammonium ratio, $\mathrm{N}_{2} \mathrm{O}$ fluxes were significantly lower at the montane site than they were in the lowlands. In part, we speculate that the low $\mathrm{N}_{2} \mathrm{O}$ fluxes resulted from the limitation of denitrification by easy drainage in the sandy soil and the consequent good aeration and perhaps from low gross fluxes of inorganic nitrogen owing to the lower temperatures. WFPS was significantly lower at $1000 \mathrm{~m}$ than at 100 and $400 \mathrm{~m}$.

The pace of decomposition is also important. High rates of decomposition consume oxygen promoting low-oxygen conditions that promote greater $\mathrm{N}_{2} \mathrm{O}$ emissions in tropical forest soils (Keller and Reiners 1994). The data on litter stocks (Table 4) show that the rate of decomposition (promoted by higher temperatures) is nearly twice as great in the lowlands as in the montane sites. Thus, low $\mathrm{N}_{2} \mathrm{O}$ emissions at montane sites could be related to low decomposition rates through the limitation in gross nitrogen transformations and through the limitation on oxygen consumption.

No single factor promoted the greatest $\mathrm{N}_{2} \mathrm{O}$ fluxes found in months of December 2006 and January 2007 at elevation $100 \mathrm{~m}$. We speculate that the high fluxes result from a combination of high temperature, elevated soil WFPS, and high rates of decomposition that could result low-oxygen conditions. In addition, we note that $\mathrm{CH}_{4}$ consumption is diminished at the same time. In this case, the association of low oxygen conditions with high $\mathrm{N}_{2} \mathrm{O}$ fluxes is corroborated by the correlation between $\mathrm{N}_{2} \mathrm{O}$ and WFPS $\left(r^{2}=0.86\right.$; $P=0.05)$ at $100 \mathrm{~m}$ (McSwiney et al., 2001). The influence of soil temperature on gas emissions is corroborated by the significant positive relation between $\mathrm{N}_{2} \mathrm{O}$ and soil temperature at $1000 \mathrm{~m}\left(r^{2}=0.5, P<0.05\right)$.

We compare our $\mathrm{N}_{2} \mathrm{O}$ emissions with the survey made by Breuer et al. (2000) adding recent emissions measurements made in tropical forests, mainly in the Amazon region (Garcia-Montiel et al., 2001; Garcia-Montiel et al., 2002; Keller et al., 2005). The median value of all these 
measurements was approximately $2.0 \mathrm{~kg} \mathrm{~N} \mathrm{ha}^{-1} \mathrm{yr}^{-1}$. Emissions measured at $400 \mathrm{~m}$ and $1000 \mathrm{~m}$ forest sites were lower than these values, and near the lower end of the spectrum of emissions. On the other hand, $\mathrm{N}_{2} \mathrm{O}$ emissions at the $100 \mathrm{~m}$ forest sites were larger $\left(3.4 \mathrm{~kg} \mathrm{~N} \mathrm{ha}^{-1} \mathrm{yr}^{-1}\right)$ than the median value, but approximately half as great as the highest observed emissions from tropical forests $\left(6-7 \mathrm{~kg} \mathrm{Nha}^{-1} \mathrm{yr}^{-1}\right) . \mathrm{N}_{2} \mathrm{O}$ emissions measured at $100 \mathrm{~m}$ were comparable to the mean flux $\left(4.7 \mathrm{~kg} \mathrm{Nha}^{-1} \mathrm{yr}^{-1}\right.$ ) found in the only other study that measured annual $\mathrm{N}_{2} \mathrm{O}$ emissions in the coastal Atlantic Forest of Brazil (Tianguá Biological Reserve, Rio de Janeiro, 170-300 m a.s.1.) (Maddock et al., 2001).

\subsection{Soil-atmosphere exchange of $\mathrm{CH}_{4}$}

Tropical rain forests can function as a significant sink for atmospheric $\mathrm{CH}_{4}$ and most studies have reported negative fluxes (Verchot et al., 1999; Breuer et al., 2000; Gut et al., 2002; Kiese et al., 2003). Data from the Atlantic Forest corroborate this finding, and the annual mean fluxes of $\mathrm{CH}_{4}$ found in this study are similar to fluxes reported by other studies conducted in tropical forests (Keller et al., 2005). Well-drained soils generally consume $\mathrm{CH}_{4}$ from the atmosphere and soil water content regulates the flux through its control on the diffusion of $\mathrm{CH}_{4}$ in the soil (Crill, 1991; Born et al., 1990). Butterbach-Bahl et al. (2004) in a study in an Australian tropical rainforests have shown that $\mathrm{CH}_{4}$ uptake was correlated with WFPS. Although weak, there was a significant $(P<0.05)$ positive correlation between WFPS and $\mathrm{CH}_{4}$ flux at the $100 \mathrm{~m}$ forest site $\left(r^{2}=0.4, P<0.05\right)$. There was no correlation between WFPS and $\mathrm{CH}_{4}$ flux at the higher altitudes. We note that temperature and moisture correlate in these systems and that when soil moisture conditions are optimal for $\mathrm{CH}_{4}$ consumption in the cooler sites $(400 \mathrm{~m}$ and $1000 \mathrm{~m}$ ), low soil temperatures probably limit the microbial activity responsible for $\mathrm{CH}_{4}$ consumption.

\subsection{Soil-atmosphere emissions of $\mathrm{CO}_{2}$}

Because of equipment malfunctions, the temporal extent of $\mathrm{CO}_{2}$ emissions measured in our study was limited to only about one-half year. Using the exponential model of flux by altitude, the integrated carbon dioxide emissions were similar at all altitudes despite the higher temperatures (Fig. 3) and the greater rates of decomposition (Table 4) in the lowlands. We may have failed to capture the true dynamics of soil $\mathrm{CO}_{2}$ flux because we did not sample in the early part of the Austral summer (Fig. 3c) when the combination of hot and wet conditions coincided with an abundant forest floor litter stock. As noted in most studies, soil $\mathrm{CO}_{2}$ emissions are tightly related to temperature and labile substrate (Joergensen et al., 1990; Kiese and Butterbach-Bahl, 2002; Davidson and Janssens, 2006; Moreira and Siqueira, 2006). In our limited observations, the largest soil $\mathrm{CO}_{2}$ emissions were observed between February and April, 2007 (Fig. 3c) when observed soil and air temperatures were highest (Fig. 1), reinforcing the evidence for a strong temperature effect.

\section{Conclusions}

Overall we found that the emissions of $\mathrm{N}_{2} \mathrm{O}$ and the uptake of $\mathrm{CH}_{4}$ by soils of the coastal Atlantic Forest of Brazil are within the range of other tropical forests of the world. We observed that $\mathrm{N}_{2} \mathrm{O}$ and $\mathrm{CO}_{2}$ emissions were lower at higher altitudes, although the nitrogen and carbon stocks were greater at higher altitudes. We speculate this contrast cannot be explained by an isolated factor but by an association of factors including air and soil temperatures, species composition (van Haren et al., 2010), soil physical and chemical properties, decomposition rates and nutrient supply. Amongst all those factors, the temperature gradient was most obvious. An apparently non-linear response of both decomposition and nitrogen cycling to elevated temperature leads to strong seasonal $\mathrm{N}_{2} \mathrm{O}$ emissions in the lowlands whereas emissions are relatively low at submontane and montane sites throughout the year. Climate change associated with increasing temperatures may result in increased in microbial activity with a consequent increase in soil $\mathrm{N}_{2} \mathrm{O}$ and $\mathrm{CO}_{2}$ emissions and soil $\mathrm{CH}_{4}$ consumption. While a response along an elevation gradient is likely to be mediated by temperature, we recognize that no single factor in this complex system can adequately predict the response of greenhouse gas fluxes to climate change.

Acknowledgements. This research was supported by the State of São Paulo Research Foundation (FAPESP) as a scholarship (2005/57549-8) and as part of the Thematic Project Functional Gradient (FAPESP 03/12595-7 to C. A. Joly and L. A. Martinelli), within the BIOTA/FAPESP Program - The Biodiversity Virtual Institute (www.biota.org.br). COTEC/IF 41.065/2005 and IBAMA/CGEN 093/2005 permit. We gratefully acknowledge the field assistance of Edmar Mazzi, Osvaldo Santos, Salvador Santos, and laboratory assistance of Fabiana Fracassi, Paulo Queiroz, Simoni Grilo and several graduate students.

Edited by: F. Carswell

\section{References}

Alves, L. F., Vieira, S. A., Scaranello, M. A., Camargo, P. B., Santos, F. A. M., Joly, C. A., and Martinelli, L. A.: Forest structure and live aboveground biomass variation along an elevational gradient of tropical moist forest (Brazil), Forest Ecol. Manage., 260, 679-691, 2010.

Arnold, J., Corre, M. D., and Veldkamp, E.: Soil N cycling in oldgrowth forests across an Andosol toposequence in Ecuador, Forest Ecol. Manage., 257, 2079-2087, 2009.

Beare, M. H., Gregorich, E. G., and St-Georges, P.: Compaction effects on $\mathrm{CO}_{2}$ and $\mathrm{N}_{2} \mathrm{O}$ production during drying and rewetting of soil, Soil Biol. Biochem., 41, 611-621, 2009. 
Born, M., Door, H., and Levin, I.: Methane consumption in aerated soils of the temperature zone, Tellus, 42A, 2-8, 1990.

Bouwman, A. F., Vanderhoek, K. W., and Olivier, J. G. J.: Uncertainties in the global source distribution of nitrous oxide, J. Geophys. Res.-Atmos. 100, 2785-2800, 1995.

Breuer, L., Papen, H., and Butterbach-Bahl, K.: $\mathrm{N}_{2} \mathrm{O}$ emissions from tropical forest soils of Australia. J. Geophys. Res. 105, 26353-26367, 2000.

Butterbach-Bahl, K., Kock, M., Willibald, G., Hewett, B., Buhagiar, S., Papen, H., and Kiese, R.: Temporal variations of fluxes of $\mathrm{NO}, \mathrm{NO}_{2}, \mathrm{~N}_{2} \mathrm{O}, \mathrm{CO}_{2}$ and $\mathrm{CH}_{4}$ in a tropical rain forest ecosystem, Global Biogeochem. Cy., 18(3), GB3012, doi:10.1029/2004GB002243, 2004.

Campo, J., Solís, E., Valencia, M. G., Litter, N.: Litter N and P dynamics in two secondary tropical dry forests after relaxation of nutrient availability constraints., Forest Ecol. Manage., 252, 33-40, 2007.

Carmo, J. B., Piccolo, M. C., Andrade, C. A., Cerri, C. E. P., Feigl, B. J., Sousa Neto, E., and Cerri, C. C.: Short-term changes in nitrogen availability, gas fluxes $\left(\mathrm{CO}_{2}, \mathrm{NO}, \mathrm{N}_{2} \mathrm{O}\right)$ and microbial biomass after tillage during pasture re-establishment in Rondônia, Brazil. Soil Till. Res., 96, 250-259, 2007.

Crill, P. M.: Seasonal patterns of methane uptake and carbon dioxide release by a temperature woodland soil, Global Biogeochem. Cy., 5, 319-334, 1991.

Davidson, E. A.: Soil water content and the ratio of nitrous oxide to nitric oxide emitted from soil, edited by: Oremland, R. S., The Biochemistry of Global Change: Radioactive trace gases, New York, Chapman and Hall, 369-386, 1993.

Davidson, E. A. and Janssens, I. A.: Temperature Sensitivity of soil carbon decomposition and feedbacks to climate change, Nature, 440, 165-173, 2006.

Davidson, E. A., Erickson, H. E., Keller, M., Veldcamp, E., and Verchot, L. V.: Testing a conceptual model of soil emission of nitrous and nitric oxides, BioScience, 50, 667, doi:10.1641/00063568(2000)050[0667:TACMOS]2.0.CO;2, 2000.

Davidson, E. A., Erickson, H. E., and Keller, M.: Nitrogen oxide fluxes and nitrogen cycling during post agricultural succession and forest fertilization in the humid tropics, Ecosystems, 4, 6784, 2001.

Doff Sotta, E., Meir, P., Malhi, Y., Nobre, A. D., Hodnett, M. and Grace, J. Soil $\mathrm{CO}_{2}$ efflux in a tropical forest in the central Amazon, Glob. Change Biol., 10, 601-617, 2004.

Firestone, M. K and Davidson, E. A.: Microbiological basis of NO and $\mathrm{N}_{2} \mathrm{O}$ production and consumption in soil, edited by: Andreae, M. O. and Shimel, D. S., Exchange of trace gases between terrestrial ecosystems and the atmosphere, New York, John Wiley \& Sons, 7-21, 1989.

Garcia-Montiel, D. C., Melillo, J. M., Steudler, P. A., Neill, C., and Cerri, C. C.: Controls on soil nitrogen oxide emissions from forests and pastures in the Brazilian Amazon, Global Biogeochem. Cy., 15, 1021-1030, 2001.

Garcia-Montiel, D. C., Melillo, J. M., Steudler, P. A., Neill, C., Feigl, B. J., and Cerri, C. C.: Relationship between $\mathrm{N}_{2} \mathrm{O}$ and $\mathrm{CO}_{2}$ emissions from the Amazon basin, Geophys. Res. Lett, 29(6), 1090, 3 pp., doi:10.1029/2001GL013830, 2002.

Grubb, P. J.: Control of forests growth and distribution on wet tropical mountains: with special reference to mineral nutrition, Annu. Rev. Ecol. Syst. 8, 83-107, 1977.
Gut, A., van Dijk, S. M., Scheibe, M., Rummel, U., Welling, M., Ammann, C., Meixner, F. X., Kirkman, G. A., Andreae, M. O., and Lehmann, B. E.: NO emission from an Amazon rain forest soil: Continuous measurement of NO flux and soil concentration, J. Geophys. Res.-Atmos., 107(D20), 8057, doi:10.1029/2001JD000521, 2002.

Joergensen, R. G., Brookes, P. C., and Jenkinson, D. S.: Survival of the soil microbial biomass at elevated-temperatures, Soil Biol. Biochem., 22, 1129-1136, 1990.

Keller, M. and Reiners, W. A.: Soil-atmosphere exchange of nitrous oxide, nitric oxide and methane under secondary succession of pasture to forests in the Atlantic lowlands of Costa Rica, Global Biogeochem. Cy., 8, 399-409, 1994.

Keller, M., Kaplan, W. A., and Wofsy, S. C.: Emissions of $\mathrm{N}_{2} \mathrm{O}$, $\mathrm{CH}_{4}$ and $\mathrm{CO}_{2}$ from tropical forests soils, J. Geophys. Res.Atmos. 91, 1791-1802, 1986.

Keller, M., Asner, G. P., Crill, P., Dias, J. D., de Oliveira, R. C., Silva, H., and Varner, R.: Soil-atmosphere exchange of nitrous oxide, nitric oxide, methane and carbon dioxide in logged and undisturbed forest in Tapajos National Forest, Brazil. Earth Interact. 9, 1-28, 2005.

Kiese, R. and Butterbach-Bahl, K.: $\mathrm{N}_{2} \mathrm{O}$ and $\mathrm{CO}_{2}$ emissions from three different tropical forest sites in the wet tropics of Queensland, Australia. Soil Biol. Biochem. 34, 975-987, 2002.

Kiese, R., Hewett, B., Graham, A., and Butterbach-Bahl, K.: Seasonal variability of $\mathrm{N}_{2} \mathrm{O}$ emissions and $\mathrm{CH}_{4}$ uptake by tropical rainforest soils of Queensland, Australia, Global Biogeochem. Cy., 17, 13, doi:104310.1029/2002gb002014, 2003.

Maddock, J. E. L., dos Santos, M. B. P., and Prata, K. R.: Nitrous oxide emissions from soil of the Mata Atlântica, Rio de Janeiro State, Brazil, J. Geophys. Res.-Atmos. 106, 23055-23060, 2001.

Marrs, R. H., Proctor, J., Heaney, A., and Mountford, M. D.: Changes in soil nitrogen-mineralization and nitrification along an altitudinal transect in tropical rain forest in Costa Rica, J. Ecol., 76, 466-482, 1988.

Martins, S. C.:Caracterização dos solos e serapilheira ao longo do gradiente altitudinal da Mata Atlântica, estado de São Paulo, Doctorate Thesis. Universidade de São Paulo, Brazil, 2010.

McSwiney, C. P., McDowell, W. H., and Keller, M.: Distribution of nitrous oxide and regulators of its production across a tropical rainforest catena in the Luquillo Experimental Forest, Puerto Rico, Biogeochemistry-US 56, 265-286, 2001.

Metzger. J. P.: Conservation issues in the Brazilian Atlantic forest. Biol. Conserv. 142, 1138-1140, 2009.

Moreira, F. M. S. and Siqueira, J. O.: Microbiologia e Bioquímica do Solo. Lavras, MG, UFLA, 2006.

Myers, N., Mittermeier, R. A., Mittermeier, C. G., da Fonseca, G. A. B., and Kent, J.: Biodiversity hotspots for conservation priorities, Nature, 403, 853-858, 2000.

Nardoto, G. B., Ometto, J. P. H. B., Ehleringer, J. R., Higuchi, N., Bustamante, M. M. C., Martinelli, L. A.: Understanding the influences of spatial patterns on $\mathrm{N}$ availability within the Brazilian Amazon Forest, Ecosystems, 11, 1234-1246, 2008.

Oliveira-Filho, A. T. and Fontes, M. A. L.: Patterns of floristic differentiation among Atlantic forests in southeastern Brazil and the influence of climate, Biotropica 32, 793-810, 2000.

Olson, J. S.: Energy storage and the balance of producers and decomposers in ecological systems, Ecology, 44, 322-331, 1963.

Piccolo, M. C., Neill, C., and Cerri, C. C.: Net nitrogen miner- 
alization and net nitrification along a tropical forest-to-pasture chronosequence, Plant Soil, 162, 61-70, 1994.

Purbopuspito, J., Veldkamp, E., Brumme, R., and Murdiyarso, D.: Trace gas fluxes and nitrogen cycling along an elevation sequence of tropical montane forests in Central Sulawesi, Indonesia, Global Biogeochem. Cy., 20, GB3010, 11 pp., doi:10.1029/2005GB002516, 2006.

Reiners, W. A., Bouwman, A. F., Parsons, W. F. J., and Keller, M.: Tropical rain forest conversion to pasture - changes in vegetation and soil Properties, Ecol. Appl. 4, 363-377, 1994.

Reiners, W. A., Gerow, K. G., and Keller, M.: Estimating rainy season nitrous oxide and methane fluxes across forest and pasture landscapes in Costa Rica. 3rd International Symposium on Ecosystem Behavior, Philadelphia, Pennsylvania, 117-130, 1997.

Ribeiro, M. C., Metzger, J. P., Martensen, A. C., Ponzoni, F. J., and Hirota, M. M.: The Brazilian Atlantic Forest: How much is left and how is the remaining forest distributed? Implications for conservation, Biol. Conserv., 142, 1141-1153, 2009.

Riley, R. H. and Vitousek, P. M.: Nutrient dynamics and nitrogen trace gas flux during ecosystem development in montane rain forest, Ecology, 76, 292-304, 1995.

Sentelhas, P. C., Pereira, A. R., Marin, F. R., Angelocci, L. R., Alfonsi, R. R., Caramori, P. H., Swart, S.: Balanços Hídricos Climatológicos do Brasil-500 balanços hídricos de localidades brasileiras. ESALQ Piracicaba, available at: http:// www.bdclima.cnpm.embrapa.br/index.php, 1999.

Shanks, R. E. and Olson, J. S.: First-year breakdown of leaf litter in southern Appalachian forests, Science, 134, 194-195, 1961.

Sollins, P.: Factors influencing species composition in tropical lowland rain forest: Does soil matter?, Ecology 79, 23-30, 1998.
Steudler, P., Jones, R., Castro, M., Melillo, J., and Lewis, D.: Microbial controls of methane oxidation in temperate forest and agricultural soils, Nato Asi. Ser. Ser. I, 39, 69-84, 1996.

Tanner, E. V. J., Vitousek, P. M., and Cuevas, E.: Experimental investigation of nutrient limitation of forest growth on tropical mountains, Ecology, 79, 10-22, 1998.

Tabarelli, M. and Mantovani, W.: Gap-phase regeneration in a tropical montane forest: the effects of gap structure and bamboo species, Plant Ecol., 148, 149-155, 2000.

Talora, D. C. and Morellato, P. C.: Fenologia de espécies arbóreas em floresta de planície litorânea do sudeste do Brasil, Revista Brasil. Bot., São Paulo, 23, 13-26, 2000.

van Haren, J. L. M., Oliveira Jr., R. C., Restrepo-Coupe, N., Hutyra, L., Camargo, P. B., Keller, M., and Saleska, S. R.: Do plant species influence soil $\mathrm{CO}_{2}$ and $\mathrm{N}_{2} \mathrm{O}$ fluxes in a diverse tropical forest?, J. Geophys. Res., 115, G03010, 9 pp., doi:10.1029/2009JG001231, 2010.

Vieira, S. A., Alves, L. F., Aidar, M., Araújo, L. S., Baker, T., Batista, J. L. F., Campos, M. C., Camargo, P. B., Chave, J., Delitti, W. B. C., Higuchi, N., Honorio, E., Joly, C. A., Keller, M., Martinelli, L. A., Mattos, E. A. d., Metzker, T., Phillips, O., Santos, F. A. M. d., Shimabukuro, M. T., Silveira, M., and Trumbore, S. E.: Estimation of biomass and carbon stocks: the case of the Atlantic Forest, Biota Neotropica, 8(2), 21-29, 2008.

Verchot, L. V., Davidson, E. A., Cattanio, J. H., Ackerman, I. L., Erickson, H. E., and Keller, M.: Land use change biogeochemical controls of nitrogen oxide emissions from soils in eastern Amazonia, Global Biochem. Cy., 13, 31-46, 1999.

Vogt, K. A. and Persson, H.: Measuring growth and development of roots, edited by: Lassoie, J. P. and Hinckley, T. M., Techniques and approaches in forest tree ecophysiology, Boca Raton, CRC Press, 477-501, 1991. 